\title{
The Application of Yoga Pranayama and Gym Ball Exercise on Labor Pain During Active Phase at Pmb Desa Blahkiuh, Abiansemal, Badung
}

\author{
Luh Putu Widiastini ${ }^{1}$, I Gusti Agung Manik Karuniadi² \\ Midwifery Study Program \\ Institute of Health Science-Bina Usada Bali \\ Badung \\ enick.dilaga@gmail.com \\ Midwifery Study Program \\ Institute of Health Science-Bina Usada Bali \\ Badung
}

\begin{abstract}
Pain Labor is a physiological and individual experience. The cause of pain in labor is a combination of ischemia (hypoxia) the muscles of the uterus and stretching that occurs in the lower segment of the uterus (then the cervix). Non-pharmacological efforts that can be done in reducing pain in the mother in the face of labor are through the Application of Yoga Pranayama and Gym Ball Exercise. The purpose of this study was to determine the effect of the application of Yoga Pranayama and Ball Exercise Gym on Labor Pain Active Phase in PMB Blahkiuh Village, Abiansemal, Badung. This research method used the Quasi Experimental Design study with Nonequivalent Control Group Design. The approach used is a prospective approach. Sample consisted 40 respondents. Respondent selected by purposive sampling and divide into control group and intervention group. Respondents in intervention group were given Yoga Pranayama and Gym Ball Exercise, while in the control group respondents were given conventional therapy. The data were analyzed using the Paired T-test to compare the results of the pre-test and post-test, and to compare intervention and control groups use Independent T-Test. Based on statistical tests obtained all $\mathrm{p}$ values $<0.05$ means that there is a significant difference between pain labor in the control and intervention group, so it can be interpreted that pain scale in intervention group is lower than control group. The conclusion of this study was there's influence on the application of Yoga Pranayama and the Ball Exercise Gym on Labor Pain in the Active Phase in PMB Blahkiuh Village, Abiansemal, Badung.
\end{abstract}

Index Terms - labor pain, active phase, yoga pranayama, gym ball exercise

\section{INTRODUCTION}

Childbirth is a physiological process, in which the result of conception (fetus and placenta) that can live outside begins with uterine contractions, cervical thinning and opening, birth of the baby and placenta that goes through another path (stomach), with the help of help or without help (mother's own strength). Several theories have been put forward by experts regarding childbirth caused by uterine contractions, which will cause the opening and thinning of the cervix, until the discharge of the fetus and placenta. These contractions cause pain that makes the mother feel uncomfortable, anxious, afraid, which in the end the pain felt will be stronger.

First-stage labor pain is cervical dilatation and lower uterine sagment with advanced distension, stretching, and trauma to muscle fibers and ligaments. Factors causing labor pain are: a). reduced oxygen supply to the uterine muscle (labor pain becomes greater if the interval between contractions is short, so that the supply of oxygen to the uterine muscle has not fully recovered), b). stretching of the 
cervix (effacement and widening), c). jaw and vagina, d). regulation and stretching of the supporting tissues of the uterus and pelvic joints during baby's contractions and descent, e). Pressure on the urinary tract, bladder and anus, f). Stretching of the pelvic floor muscles and vaginal tissue, g). challenges and challenges that can be expelled by releasing large amounts of stress hormones (epinephrine, norepinephrine, etc.) that cause long and more severe labor pain [1].

Labor pain can cause stress which causes excessive release of hormones such as catecholamines and steroids. This hormone can cause smooth muscle tension and vasoconstriction of blood vessels. This can reduce uterine contractions, decrease uteroplacental circulation, blood flow and oxygen to the uterus, and cause uterine ischemia which makes the impulses increase more. Non-pharmacological methods that are currently being developed include acupuncture, hypnosis, hydrotherapy, physical exercise during pregnancy, massage and reflexology, and yoga [2,3].

Pranayama Yoga is one of the training techniques to get to know yourself so that you can further analyze your thoughts and actions. Exercise is done through bodily postures (asanas), breathing (pranayama), and relaxation techniques so that they can develop natural intuitive intelligence and help the mind to be focused, and ultimately can make changes in the form of peace of mind and focused attention [4].

Pelvic Rocking with a Gym Ball is to increase the size of the pelvic cavity by rocking the pelvis with the ball and slowly swinging the hips forwards and backwards, the right, left, and circular sides. Pelvic rocking can help the mother in an upright position, staying upright when in labor will allow the uterus to work as efficiently as possible by making the pelvic plane wider and open. In other words it can stimulate dilation and widen the pelvic outlet. Sitting straight on the ball, the earth's gravity will help the fetus or the lowest part of the fetus to descend immediately to the pelvis so that the delivery time is shorter or shorter [5].

Based on the results of a preliminary study conducted by researchers of 30 Maternity Mother on the First Stage of Active Phase using NRS, it was found that 23 out of 30 mother experiencing severe pain. Only 2 mothers who knew about Yoga Pranayama and Gym Ball Exercise Against Labor Pain in First Stage Active Phase but they didn't use it to reduce pain during labor. This study aims to determine the application of Yoga Pranayama and Gym Ball Exercise Against Labor Pain in First Stage Active Phase Maternity Mothers in PMB Blahkiuh Village, Abiansemal, Badung.

\section{METHOD}

This research design uses Quasi Experimental Design with Nonequivalent Control Group Design. The group was divided into 2, control groups who were not given Pranayama Yoga and Gym Ball Exercise (O1) and (O2) and treatment groups $(\mathrm{O} 3)$ and $(\mathrm{O} 4)$ were given Pranayama
Yoga and Gym Ball Exercise. The questionnaire was filled in twice before $(\mathrm{O} 1),(\mathrm{O} 3)$ and after $(\mathrm{O} 2),(\mathrm{O} 4)$ treatment in the treatment and control groups. The difference between 01 and 02 is assumed to be the effect of conventional therapy in the women given, compared with $\mathrm{O} 3$ and $\mathrm{O} 4$ given by Yoga Pranayama and Gym Ball Exercise. The approach used is a prospective approach. In this case Pranayama Yoga and Gym Ball Exercise affect labor pain in the First Stage of Active phase. The study was conducted by researchers. the first thing to do was to measure labor pain when I was active in 20 mothers from the control group and 20 mothers from the treatment group using NRS (Numeric Rating Scale). NRS is a horizontal line with a scale of numbers ranging from 0 to 10 , the number 0 indicates no pain, 1-3 minor injuries, 4-6 moderate pain, grinning, can display the location of pain, describe it, and can be followed by orders properly), 7-9 severe recovery, able to respond to challenges, can indicate the location of treatment, unable to describe, cannot be overcome by using transfer, deep breathing, and distraction), and 10 severe injuries. After that, the yoga session is given a yoga intervention every time the mother feels a contraction and the gym ball exercises the entire contraction. In the control group only guided to take a deep breath during contractions, and pulled the contractions. After treatment, labor pain measurements were performed again using NRS in both treatment and control groups.

Statistics are used to analyze data by describing or describing data on Pranayama Yoga and Gym Ball Exercise on labor pain in the active phase I phase without making conclusions that apply to the population. To measure the difference in labor pain in the first phase of the active phase of the pre-test and post-test sample using the Paired Sample-t Test because the data is normally distributed. This study has passed the ethical test conducted at the STIKES Bina Usada Bali health research ethics commission (no. 184/EA/KEPK-BUB-2019).

\section{RESULT}

\section{A. Demographic Characteristic}

The total respondents who participated in this study were 40 people. Based on age characteristics, $20 \%$ are classified as mothers who are too young, 60\% are of healthy reproductive age, and $20 \%$ are classified as mothers who are too old. Based on parity characteristics, $40 \%$ of mothers are primigravidas and $60 \%$ are multigravidas. $70 \%$ have a moderate level of education and $30 \%$ have a high level of education.

\section{B. Pain Levels in the Treatment and Control Groups}

Table 1 showed that in the control group there was a decrease in the mean pain value of 6.9 before being given treatment in the form of taking a deep breath during contraction, and resting between contractions and dropping 
to 5.75 after being given later treatment from the results of different tests before and after treatment in the control group with using the t test, $\mathrm{p}$ values $<0.05(0.02)$ showed that there were significant differences in the level of pain before and after treatment in the control group.

Table 1. Distribution of pain levels before and after the administration of conventional therapy in the control group

\begin{tabular}{cccccc}
\hline Variable & Statistic & Pre & Post & t count & p value \\
& & & & & \\
\hline Pain & Mean & 6,90 & 5,75 & 2,382 & 0,02 \\
& SD & 1,80 & 1,07 & & \\
\hline
\end{tabular}

Table 2 showed that in the treatment group there was a decrease in the average value of pain that is 6.95 before being given treatment in the form of Yoga Pranayama and Gym Ball Exercise and dropped to 4.6 after being given treatment, then from the results of different tests before and after treatment in the control group using the $t$ test $p$ value obtained from the value of $\mathrm{p}=0.01(\mathrm{P}<0.05)$ so that there are differences in the level of labor pain before and after being given Yoga Pranayama and Gym Ball Exercise in the Treatment Group.

Table 2. Distribution of Pain Levels Before and After Given Pranayama Yoga and Gym Ball Exercise in the Treatment Group

\begin{tabular}{cccccc}
\hline Variable & Statistic & Pre & Post & t count & $\begin{array}{c}\mathrm{p} \\
\text { value }\end{array}$ \\
\hline Pain & Mean & 6,95 & 4,60 & 4,009 & 0,01 \\
& SD & 1,731 & 1,231 & & \\
\hline
\end{tabular}

Table 3 showed $t$ test to analyze differences in pain levels in the treatment and control groups, $p$ values $<0.05(0.03)$ means that there are significant differences in labor pain in the control and treatment groups, so it can be interpreted that the pain scores in the treatment group are lower than those in the treatment control group.

Table $3 \mathrm{t}$ value for comparing treatment and control groups in pain level testing

\begin{tabular}{lcccc}
\hline Variable & \multicolumn{2}{c}{ Groups } & T count & P value \\
\cline { 2 - 3 } & Control & Treatment & & \\
\cline { 2 - 3 } & $\bar{X} \bar{X}_{ \pm \mathrm{SD}}$ & $\bar{X}_{ \pm \mathrm{SD}}$ & & \\
\hline Pain & $5,75 \pm 1,070$ & $4,60 \pm 1,231$ & 3,153 & 0,03 \\
\hline
\end{tabular}

\section{DISCUSSION}

Labor pain is pain which results from movements (contractions) of the uterus that function subjectively, rhythmically with an increase in the frequency and severity used to expel the baby. The intensity of pain is proportional to the contraction pressure and the pressure that occurs, healing of uterine pressure in the form of baby's dilated pressure on the pelvic structure followed by stretch and tear of the birth canal.

Labor pain is unique and different for each individual because there is no difference with the physical condition, but also related to the psychological condition of the mother at the time of delivery. Psychological conditions that cause excessive fear and anxiety will cause or worsen physical problems.

In the results of this study it was found that there was a significant difference between labor pain in the group given pranayama yoga and gym ball exercise with the control group as evidenced by the $\mathrm{p}$ value $<0.05(0.03)$. This is in line with the results of similar studies previously conducted [6][7][8].

Yoga as a supportive intervention that is beneficial for various diseases associated with pain. Healthy individuals with labor pain, the practice of yoga has a very strong effect [9]. Yoga breathing techniques can strengthen the respiratory system, calm the nervous system, help reduce or eliminate various types of addictions and can strengthen the immune system. Yoga breathing plays an important role in the body's metabolism, namely the body's process of breaking down nutrients. The real benefit that can be felt from this pranayama yoga practice is that it reduces fatigue, thoughts and emotions become calm [4].

The mechanism of yoga breathing exercises for physical changes that occur in the body begins with the creation of an atmosphere of conscious relaxation that systematically leads to a deep relaxed state. The creation of an atmosphere of relaxation will eliminate the sounds in the mind so that the body will be able to release muscle tension. When the body begins to relax, breathing becomes slow and deep, so that the respiratory system can rest. The slowing of this breathing rhythm will make the heart rate slower and have a positive effect on the entire circulatory system and the heart to rest and undergo a rejuvenation process. The sympathetic nervous system that is always ready for action receives messages to relax while the parasympathetic nervous system responds to relaxation. In addition to sympathetic nerves, messages for relaxation are also received by the endocrine glands which are responsible for most emotional and physical states [4].

The exercise of gym ball exercises can help reduce the scale of pain felt by the mother because the mother feels relaxed and relaxed so that it can reduce the tension due to the expenditure of endorphine [8]. Relaxation obtained from birth ball exercises is one of the non-pharmacological pain controllers. The use of relaxation techniques and breathing exercises preparation for labor lies in the physiology of the autonomic nerve, where the autonomic nerve is a peripheral nervous system that maintains homeostasis in the individual's internal environment so that the muscles become less tired so that the mother can reduce her pain by reducing pain sensations and control reactions to pain [7].

\section{CONCLUSION}

This study found that there's influence on the application of Yoga Pranayama and the Ball Exercise Gym on Labor Pain in the Active Phase in PMB Blahkiuh Village, Abiansemal, Badung. The results of this study can provide information health care workers who provide care to 
Journal of a Sustainable Global South, p-ISSN: 2579-6062

maternity women in reducing pain during delivery process.

\section{ACKNOWLEDGMENT}

The Author would like to acknowledge financial support for this study from Institute of Health Science Bina Usada Bali.

\section{REFERENCES}

[1] Simkin P.W., Keppler J.A., "Pandu Lengkap Kehamilan, Melahirkan Bayi", Jakarta Arcan, 2007.

[2] Jahdi, F., Sheikhan F., Haghani H., Sharifi B., Ghaseminejad A., Khodarahmian M., et al., "Yoga during pregnancy: The effects on labor pain and delivery outcomes (A randomized controlled trial)", Complement Ther Clin Pract, 2017.

[3] Adams, J., Frawley J., Steel A., Broom A., Sibbritt D., "Use of pharmacological and non-pharmacological labour pain management techniques and their relationship to maternal and infant birth outcomes: examination of a nationally representative sample of 1835 pregnant women", Midwifery, 2015.

[4] Worby, "Memahami Segalanya tentang Yoga: Tingkatkan Kekuatan, Kelenturan, dan Kesehatan Anda, In Y.I Wahyu (Eds) . Yoga: The Everything Yoga Book", Jakarta: Kharisma Publishing Group, 2007.

[5] Aprilia, Y., "Gentle Birth-Melahirkan Nyaman Tanpa Rasa Sakit", Jakarta: Grasindo, 2011.

[6] Indrayani, T., Riyanti S.M., "Pengaruh Penggunaan Birthing Ball Terhadap Penurunan Skor Nyeri Pada Ibu Bersalin Kala I Fase Aktif di Klinik Bersalin Bekasi Tahun 2018", J Akad Keperawatan Husada Karya Jaya, 2019.

[7] Purnama W.I., "Tarawang VM, Nurihsan J. Pengaruh Senam Hamil Menggunakan Birth Ball Terhadap Persepsi Nyeri Pada Primigravida Selama Persalinan", J Kesehatan Almuslim, 2019.

[8] Kurniawati A., Dasuki D., Kartini F., "Efektivitas Latihan Birth Ball Terhadap Penurunan Nyeri Persalinan Kala I Fase Aktif pada Primigravida", J Ners dan Kebidanan Indones, 2017.

[9] Büssing, A., Ostermann T., Lüdtke R., Michalsen A., "Effects of yoga interventions on pain and pain- associated disability: a metaanalysis", J Pain, 2012. 